\title{
AUREOMYCIN (CLORTETRACYCLINE) FEEDING TEST ON CALVES AND HEIFERS SUFFERING FROM INDIGESTION
}

\author{
S. HaAranen \\ Institute of Pharmacology, Veterinary College, Helsinki
}

Recevied January 21, 1959

A small addition of certain antibioties to the daily feed often produces a notable improvement in the condition of the test animal. The feed intake per growth $\mathrm{kg}$ diminishes and the daily additional growth increases. The influence of the antibiotics is thought to be based on their antibacterial effect and, in fact, the most noticeable results have been achieved with animals kept in dirty sheds and suffering from various infections. The antibiotic additive diminishes the effect of detrimental infections. It was decided to test the effect of chlortetracycline (= Aureomycin) on calves and heifers of $4-9$ months suffering from chronic indigestion.

\section{Procedure}

Six calves and heifers (4 Ayrshires and 2 Finnish polledbreed) of $4-9$ months were selected as the test animals. They showed clinical symptoms of chronic indigestion. The animals were big-bellied, shaggy and lean. Many of them had suffered from diarrhoea. The visible mucosa were anaemic. 6 animals of the same age and in the same condition were weighed as controls. Both groups were given similar feeds: timothy-hay and fresh water ad libitum, and $0,5 \mathrm{~kg}$ of oat meal per day to each animal. The two youngest — one in each group - were given 3 litres of skimmed milk. The animals of the test group were given in their oat meal Aurofac, ${ }^{1}$ an antibiotic preparation, mixed in the ratio 1:50. The active ingredient - chlortetracycline - totals $80 \mathrm{mg}$ per $05 \mathrm{~kg}$ of flour, and this was the daily dose given to the test animal. The test period was 50 days. The administration of Aurofac was interrupted for technical reasons between the $33 \mathrm{rd}$ and the $40 \mathrm{th}$ days of the test. The following measurements were taken before, during and after the test: live weights,

1 Aureomycin is the trade name of chlortetracycline. The chlortetracycline used in the experiment was contained in the Aurofac 2A preparation by American Cyanamid Co. Its active ingredients are: 3.6.g. of chlortetracycline per $1 \mathrm{lb}$. of Aurofac. 
Table 1. Aureomycin test on heifers, with indigestion.

Increases in the measured values for the test and control groups as a whole and as averages; also the differences between the test and control groups, and the computed method errors of single determinations calculated on the basis of triple measurements, $\mathrm{n}=42$.

\begin{tabular}{|c|c|c|c|c|c|}
\hline & $\begin{array}{c}\text { Live } \\
\text { weight } \\
\text { increase, } \\
\text { kg }\end{array}$ & $\begin{array}{c}\text { Length } \\
\text { increase, } \\
\mathrm{cm}\end{array}$ & $\begin{array}{l}\text { Chest } \\
\text { circum- } \\
\text { ference } \\
\text { increase, } \\
\mathrm{cm}\end{array}$ & $\begin{array}{c}\text { Height } \\
\text { of } \\
\text { withers } \\
\text { increase, } \\
\mathrm{cm}\end{array}$ & $\begin{array}{c}\text { Tub. cox. } \\
\text { breadth } \\
\text { increase, } \\
\mathrm{cm}\end{array}$ \\
\hline \multicolumn{6}{|l|}{ Test group } \\
\hline \multicolumn{6}{|l|}{6 heifers } \\
\hline Whole group & 86.7 & 56.0 & 39.0 & 11.0 & 10.0 \\
\hline Average & $14.45 \pm 3.83^{*}$ & $9.33 \pm 3.40^{*}$ & $6.50 \pm 2.05^{*}$ & $1.8 \pm 1.43$ & $1.7 \pm 0.72$ \\
\hline \multicolumn{6}{|l|}{ Control group } \\
\hline \multicolumn{6}{|l|}{6 heifers } \\
\hline Whole group & 38.9 & 20.0 & 26.0 & 7.0 & 4.0 \\
\hline Average & $6.48 \pm 2.89$ & $3.33 \pm 1.04^{*}$ & $4.33 \pm 2.01$ & $1.2 \pm 0.82$ & $0.7 \pm 0.46$ \\
\hline \multicolumn{6}{|l|}{ Difference: } \\
\hline \multicolumn{6}{|l|}{ For the } \\
\hline Average & $\begin{array}{c}47.8 \\
7.97 \pm 4.37\end{array}$ & $\begin{array}{c}36.0 \\
6.0 \pm 3.24\end{array}$ & $2.17 \pm 3.22$ & $\begin{array}{r}4.0 \\
0.6 \pm 1.51\end{array}$ & $\begin{array}{c}6.0 \\
1.0 \pm 0.83\end{array}$ \\
\hline \multirow{2}{*}{$\begin{array}{l}\text { Method } \\
\text { errors }\end{array}$} & not & & & & \\
\hline & calculated & $\pm 0,20$ & $\pm 0,70$ & $\pm 0,28$ & $\pm 0,06$ \\
\hline
\end{tabular}

No differences in rectal temperatures, heart and respiratory rates could be demonstrated in any combination and therefore the data are excluded.

lenghts (cart cariniformis-tuber ischii), chest circumference (at the cart. xiphoidea), height of withers, pelvic breadth at the tubera coxae, rectal temperature, heart and respiration rates $(9$, Table 1$)$. Blood samples were taken concurrently and the animal were photographed. The following blood serum determinations were made: calcium, inorganic phosphorus, magnesium, potassium, copper and sodium (Table 2). Type estimation before and after the test was made subjectively taking account of the hairy coat, skin scaling and licking. The distortion of the joints and osteomalacia, the so-called mindigestion typen and the muscularity of the back were evaluated. The test and control groups were kept in adjacent pens of c. $5 \times 5 \mathrm{~m}$ The cattle shed temperature ranged during the test from $+8^{\circ}$ to $+15^{\circ} \mathrm{C}$.

\section{Results}

Not a single case of illness occurred during the test in either group. As the heifers were suffering from indigestion, the chlortetracycline dose employed was slightly higher than that recommended in the literature; $10 \mathrm{mg}$ daily per $50 \mathrm{~kg}$ of live weight as the optimal dose (8). Chlortetracycline is fed $200-800 \mathrm{mg}$ per $50 \mathrm{~kg}$ 
Table 2. Aureomycin test on heifers with indigestion.

Averages for certain minerals in the blood serum at the beginning and end of the test, their differences, and estimates of the average changes in the mineral content of the material as a whole.

$$
\mathrm{Ca} \mathrm{mg} \% \quad \mathrm{Mg} \mathrm{mg} \% \quad \mathrm{P} \mathrm{mg} \% \quad \mathrm{~K} \mathrm{mg} \% \quad \mathrm{Cu} \mathrm{mg} \% \quad \mathrm{Na} \mathrm{mg} \%
$$

$\begin{aligned} & \text { Test group } \\ & 6 \text { heifers }\end{aligned}$
$\begin{array}{lllllll}\text { Before } & 11.30 \pm 0.11 & 1.97 \pm 0.02 & 4.86 \pm 0.03 & 21.20 \pm 2.51 & 0.091 \pm 0.009 & 305.00 \pm 11.15 \\ \text { After } & 10.67 \pm 0.20 & 1.95 \pm 0.01 & 4.71 \pm 0.05 & 23.15 \pm 1.88 & 0.055 \pm 0.011 & 327.20 \pm 11.25\end{array}$

Difference $-0.63 \pm 0.13^{* *}-0.02 \pm 0.04-0.15 \pm 0.80 \quad 2.05 \pm 0.73^{*}-0.036 \pm 0.018 \quad 21.80 \pm 5.63^{*}$

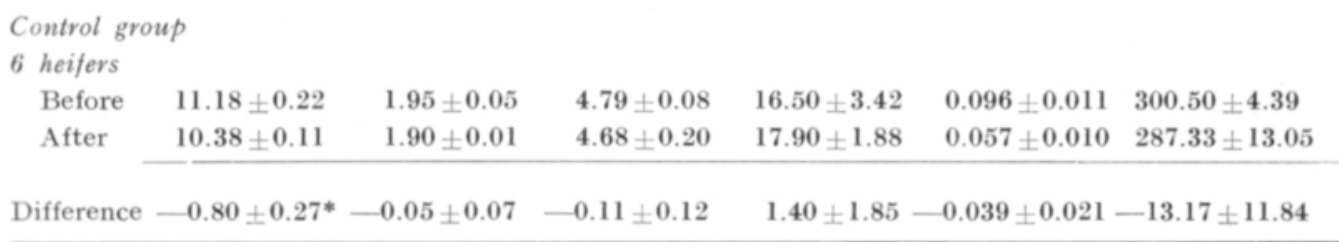

Estimated

average

changes in $-0.72 \pm 0.15-0.011 \pm 0.04 \quad-0.20 \pm 0.03 \quad 1.83 \pm 0.92^{*}-0.031 \pm 0.010 \quad(4.33 \pm 5.99)$

the material

as a whole

As none of the differences (except sodium) between average changes in the test and control groups were statistically significant, the changes were combined and estimates calculated. Hence they are illustrative of the changes taking place during the test in the averages of the material as a whole.

live weight per day to calves of $3-4$ months without any detrimental effects (2). On the other hand, a daily dose of $600 \mathrm{mg}$ to steers weighing c. $275 \mathrm{~kg}$ caused diarrhoea and lack of appetit (3). The present author has gained similar experiences in his practice. The average weight of the animals in the test group was $137.5 \mathrm{~kg}$ $(110.4-182.3 \mathrm{~kg}$ ) and the optimal dose would consequently have been c. $27 \mathrm{mg}$. In the present test it was $80 \mathrm{mg}$ per diem.

As can be seen in Table 1 , the increases in the average live weight, length, chest circumference, height of withers and pelvic breadth were greater than the corresponding values in the control group. The increases in live weight, length and chest circumference were statistically nearly significant $(0.01<\mathrm{P}<0.05)$ in the test group and the increase in length nearly significant $(0.01<\mathrm{P}<0.05)$ in the control group. The other increases were not statistically significant. The differences between the increases in the test and control groups were not significant, probably chiefly because the material was too small. The average daily additional growth was $285 \mathrm{~g}$ in the test group and $108 \mathrm{~g}$ in the control group.

Table 2 gives the changes in some minerals of the blood serum during the test. There were no other statistically significant differences between the test and control 
groups except in $\mathrm{Na}$. $(\mathrm{P}<0.001)$. It has been established that chlortetracycline, oxytetracycline, penicillin and becitracin increases the plasma calcium content in chick (7). In the present material, no corresponding effect could be seen with any certainty. However, taking the material as a whole, a drop was established incalcium and copper and an increase in potassium during the test. In the test group, the calcium drop was statistically significant, and likewise the potassium and sodium increase. This might have been due in part to the fact that the animals were moved in December from cold pen yards into the warm cattle shed; if this is so, it would agree with earlier results obtained in cold pen yards (5).

No changes were observed in the hairy coat. All the animals perspired and licked themselves after the transfer indoors. No changes were found during the test in the symptoms indicative of rachitis (large epiphyses, distorted joints ect.) nor in the muscularity of the back. There was no diarrhoea during the test although some of the animals had suffered from it previously.

No changes in the so called "indigestion types" could be observed subjectively and after the test the animals were to be considered as before as mindigestion typen heifers.

\section{$S u m m$ ary}

6 heifers of $4-9$ months suffering from indigestion were given oat meal containing $80 \mathrm{mg}$ of Aureomycin for 43 days. 6 similar heifers, serving as controls, were kept on the same diet and in the same shed. The average daily additional growth of the group receiving aureomycin was $285 \mathrm{~g}$; the corresponding additional growth of the control groups was $108 \mathrm{~g}$. The average increases for the test and control group, respectively, were: live weight $14.45 \mathrm{~kg} / 6.48 \mathrm{~kg}$, length $9.33 \mathrm{~cm} / 3.33 \mathrm{~cm}$, chest circumference $6.50 \mathrm{~cm} / 4.33 \mathrm{~cm}$, height of withers $1.8 \mathrm{~cm} / 1.2 \mathrm{~cm}$, pelvic breadth at the tubera coxae $1.7 \mathrm{~cm} / 0.7 \mathrm{~cm}$. Serum calcium and copper fell and potassium rose in the material as a whole. There were no statistically significant differences between the test and control groups except in $\mathrm{Na}$, which rose in the test and fell the control groups.

In view of the small size of each group and the nevertheless nearly significant difference in average weights $(0.05<\mathrm{P}<0.1)$, it would seem that aureomycin additive in the feed was beneficial for the heifers in these conditions. Economic consiferations will decide whether it is generally advisable to resort to aureomycin additive. The blood changes were regarded as being due to the transfer of the animals from the cold winter air indoors to a warm shed.

\section{REFERENCES}

(1) Anderson, P. 1953. Aureomycinets inverkan på våmfloran hos mindre idisslare. NVM, 5: 636.

(2) Bartley, E. E.: Wheatcroft, K. L., Claydon, T. J., Fountaine, F. C. and Parrish, D. B. 1951. Effects of feeding Aureomycin to dairy calves. J. A. Sci. 10: 1036.

(3) Bell, M. C. Whitehair, C. K., and Gallup, W. D. 1950. The effect of Aureomycin on digestion in steers. J. Anim. Sci 1950. 1951 ref. 4. 
(4) Elliot, R. F., and Maddock, H. M.: The continuous feeding of Aureomycin to beef Cattle. American Cyanamid Co. Fine Chem. Techn. Bull. N:o 9.

(5) Hanranen, S.: Tiourasiilikoe kasvavilla hiehoilla. 1959. Own investigations in print.

(6) Jukes, T. H.: Antibiotics in Nutrition. Monograph by American Cyanamid Co. Fine Chemic. Techn. Bull. N:o 3. New York.

(7) Shaffner, C. S.: and Bogdonoff, P. D. 1954. Antibiotics and Calcium merabolism. Poultry Sci. 33: 7 .

(8) Quarre, C.: and Richins, P.: ref. 4.?

(9) Weber, F. 1957. Die statistischen und genetischen Grundlagen von Körpermessungen am Rind. Diss. Berlin.

S E L O T U S :

AUREOMYSIINIKOE KASVAVILLA INDIGESTIOVASIKOILLA JA -HIEHOILLA

\section{S. HAARANEN}

Eläinlääketieteellinen Korkeakoulu, Farmakologian Laitos, Helsinki

6:lle, 4-9 kk ikäiselle hieholle, joilla kliinisesti esiintyi ns. indigestio, annettiin $0.5 \mathrm{~kg}$ :ssa kaurajauhoa $80 \mathrm{mg}$ aureomysiiniä (klortetrasykliini) p:ssä 43 päivän aikana, 6 muun samanlaisen hiehon ollessa vertailueläiminä. Aureomysiiniä saaneiden hiehojen keskimääräinen painonlisäys p:ssä oli $285 \mathrm{~g}$ — vertailueläinten vastaavan lisäyksen ollessa $108 \mathrm{~g}$. Koeajalla tapahtuneet keskimääräiset lisäykset koe/vertailueläimillä olivat: paino $14.45 \mathrm{~kg} / 6.48 \mathrm{~kg}$, kehon pituus $9.33 \mathrm{~cm} / 3.33 \mathrm{~cm}$, rinnan ympärys $6.50 \mathrm{~cm} / 4.33 \mathrm{~cm}$, säkäkorkeus $1.8 \mathrm{~cm} / 1.2 \mathrm{~cm}$ ja lantion leveys $1.7 \mathrm{~cm} / 0.7 \mathrm{~cm}$. Veren seerumin $\mathrm{Ca}$ ja $\mathrm{Cu}$ laski ja $\mathrm{K}$ nousi kokeen aikana koko materiaalilla. Koe- ja vertailuryhmien välillä oli tilastollisesti merkitsevä ero ainoastaan Na:ssa $(\mathrm{P}<0.001)$, Na nousi koe- ja laski vertailuryhmässä. 